\title{
HUBUNGAN POLA ASUH ORANG TUA DENGAN PERKEMBANGAN PSIKOSOSIAL ANAK DI TK PKK XI WINONG GEMPOL KABUPATEN PASURUAN
}

\author{
Yulianto $^{1}$, Yufi Aris Lestari ${ }^{*}$, Elok Diniarti Suwito ${ }^{1}$ \\ ${ }^{1}$ STIKES Dian Husada Mojokerto \\ *Correspondence: \\ Yufi Aris Lestari \\ Email: yufiarislestari@gmail.com
}

\begin{abstract}
Background: Pola asuh orang tua merupakan interaksi antara orang tua kepada anak dalam bentuk pengasuhan atau mendidik sebagai wujud pertanggung jawaban terhadap anak. Perkembangan psikososial anak adalah suatu perkembangan dimana anak dalam tahap inisiatf vs rasa bersalah.

Purpose: Penelitian ini bertujuan untuk menganalisis hubungan pola asuh orang tua dengan perkembangan psikososial anak di TK PKK XI Winong Kecaamatan Gempol Kabupaten Pasuruan.

Method: Desain penelitian yang digunakan adalah Analitik Cross Sectional. Populasi pada penelitian ini adalah seluruh orang tua murid di TK PKK XI Winong Kecamatan Gempol Kabupaten Pasuruan yang berjumlah 41 orang, dan besar sampel dalam penelitian ini sebanyak 37 orang. Variabel pertama dalam penelitian ini adalah pola asuh dan variable keduanya adalah perkembangan psikososial anak. Alat ukur yang dipakai dalam penelitian ini berupa kuesioner.

Results: Hasil penelitian yang diperoleh dari 37 responden, didapatkan bahwa 56,8 \% orang tua menerapkan pola asuh demokratis. Lalu untuk perkembangan psikososial didapatkan 73,0 \% menunjukkan perkembangan psikososial inisiatif. Berdasarkan hasil analisa yang menggunakan uji korelasi Speraman Rho di peroleh $\mathrm{p}=0,00<\alpha=0,05$ terdapat hubungan antara pola asuh orang tua dengan perkembangan psikososial anak di TK PKK XI Winong Kecamatan Gempol Kabupaten Pasuruan.

Conclusion: Dari hasil penelitian yang telah dilakukan menunjukkan bahwa ada hubungan antara pola asuh orang tua dengan perkembangan psikososial anak di TK PKK XI Winong Kecamatan Gempol Kabupaten Pasuruan, artinya bahwa jika orang tua tidak terlalu membatasi imajinasi dan keinginan anak maka dengan sendirinya rasa inisiatif anak akan berkembang.
\end{abstract}

Key words: pola asuh, perkembangan psikososial

\section{PENDAHULUAN}

Pada masa perkembangan psikososial rasa keingintahuan anak dan inisiatif terhadap lingkungan, perkembangan keterampilan baru. Hal ini sesuai dengan yang diungkapkan oleh Erikson, dalam (Potter dan Perry, 2005), Pola asuh adalah suatu pengajaran orang tua dalam mengasuh anak mereka, khususnya yang berhubungan dengan kedisiplinan, dimana orangtua berusaha keras mengajarkan kepada anak-anak apa yang mereka perlu ketahui dan kerjakan agar menjadi orang bahagia, percaya diri, dan dapat bertanggung jawab di masyarakat, akan tetapi bukan hanya orangtua yang bertugas menjalankan pendidikan, anak juga mengajarkan kepada orangtua bagaimana harus bersikap di hadapan anak (Edwards, 2006). Menurut Wong (2008) pola asuh dikelompokkan 
dalam tiga tipe yaitu pola asuh otoriter, pola asuh demokratis dan pola asuh permisif. Data yang muncul dimasyarakat masih banyak orang tua yang belum dapat memberikan asuhan yang sesuai dengan perkembangan psikososial anaknya.

Hampir 50\% anak usia 1-3 tahun di 54 negara maju menunjukan beberapa simptom gangguan perilaku anti sosial yang dapat berkembang menjadi gangguan perilaku tetap dikemuclian hari. Fenomena ini terjadi di negara misalnya di Kanada dan Selandia baru menunjukan sekitar 5-7\% anak mengalami anti sosial, selain itu akibat dari pola pengasuhan yang salah anak bisa menjadi depresi sebagai gambaran di Amerika menunjukan 1\% pada anak usia 1-3 tahun, 2\% usia sekolah, dan 5-8\% pada usia remaja yang mengalami depresi. Di Indonesia sendiri walau belum ada angka pasti, namun dan jumlah anak yang terlibat kejahatan hukum atau kenakalan dapat diprediksikan kalau hal tersebut sebagai akibat dari pola pengasuhan yang salah di awal tahun perkembangan (Devi, 2005). Berdasarkan hasil studi pendahuluan yang diambil pada tanggal 14 November 2014 didapatkan dari kepala sekolah TK PKK XI Winong Kecamatan Gempol Kabupaten Pasuruan bahwa kelas A nilai anak yang menurun sebesar 10\% dan kelas B sebanyak 5\% dan untuk anak yang kurang memperhatikan di dapatkan 5\% dari kelas A dan 20\% dari kelas B di yang prestasi nilainya menurun. Dan $80 \%$ dari orang tua murid tersebut keduanya bekerja, $20 \%$ hanya salah satunya yang bekerja.

Menurut penelitian yang dilakukan oleh sopiah pada tahun 2013 di Kematan Sukalarang Kabupaten Sukabumi menunjukkan bahwa orang tua yang menerapkan tipe pola asuh demokratis dengan jumlah 92 responden, perkembangan psikososial anak tahap inisiatif ada 76 responden $(82,6 \%)$ dan perkembangan psikososial tahap rasa bersalah sebanyak 16 responden $(17,4 \%)$. Responden dengan pola asuh otoriter sebanyak 26 dari orang terdiri dari 9 anak (34,6\%) pada tahap inisiatif, 17 anak $(65,4 \%)$ pada tahap rasa bersalah. Orang tua yang menerapkan tipe pola asuh permisif sebanyak 52 responden dengan perkembangan psikososial anak pada tahap inisiatif sebanyak 9 responden $(17,3 \%)$, sedangkan anak dengan perkembangan pada tahp rasa bersalah sebesar 43 responden $(82,7 \%)$. Tipe pola asuh demokratis merupakan tipe pola asuh terbanyak yang diterapkan oleh orang tua kepada anak karena tipe pola asuh demokratis mempunyai prinsip kebebasan yang dijalankan dalam segala aspek kegiatan pada keluarga, sehingga dengan tipe pola asuh demokratis membuat orang tua benar-benar memperhatikan anak sebagai individu yang utuh lahir batin dan tidak sedikitpun mengarahkannya secara otoriter (Rubestaelisa, 2008). Walgito (2004) menjelaskan bahwa, orang tua yang memiliki sikap otoriter menyebabkan anak tidak memiliki inisiatif karena takut berbuat kesalahan, menjadi anak penurut dan anak kurang atau tidak mempunyai tanggung jawab. Orang tua menuntut anak agar semakin bertanggung jawab sesuai dengan perkembangan umurnya, sedangkan anak takut disalahkan sehingga sering terjadi konflik antara orang tua dengan anak.anak sangat membutuhkan hubungan social yang baik antara anggota keluarga atau dengan lingkungannya. Pada keluarga seperti ini yang menerapkan pola asuh otoriter, anak merasa kepentingan dan hobinya tidak diperdulikan atau dianggap tidak penting. 
Saat anak berusaha menarik perhatian kedua orang tuanya atau berusaha mengukuhkan diringa, ternyata sosok otoriterlah yang dihadapinya, bahkan terkadang hukumanlah yang didapatkannya, sehingga anak menjadi kecewa dan akhirnya frustasi oleh karena itu sikap dan perlakuan orang tua banyak menetukan keberhasilah anak dalam belajar. Tuntutan orang tua yang terlalu tinggi akan menjadi beban bagi anak dan dapat menimbulkan putus asa dan rnedah diri (Mighwar,2006).orang tua yang memberikan kebebasan kepada anak dapat menjadikan anak menjadi mudah melakukan suatu hal yang berguna untuk dirinya kelak, namun hal ini harus disertai pengawasan orang tua karena malah akan membuat anak menjadi sulit diatur. Menurut Baumrind 1971 (dalam santrock,2011), orang tua yang menerapkan tipe permisif tidak memberikan struktur dan batasan yang tepat bagi anak. Orang tua tipe ini cenderung mempercayai bahwa ekspresi bebas dari keinginan hati dan harapan sangatlah penting bagi perkembangan psikologis. Orang tua menyembunyikan ketidak sabaran, kemarahan atau kejengkelan pada anak.

Menurut Chabib Thoha (1996:109) mengemukakan bahwa pola asuh orang tua adalah suatu cara terbaik yang dapat ditempuh orang tua dalam mendidik anak sebagai perwujudan dari rasa tanggung jawab kepada anak. Meskipun kedua orang tua dari murid tersebut bekerja tetapi alangkah baiknya mereka juga menyempatkan waktu untuk memberikan perhatian pada anaknya dengan cara bermain bersama ataupun belajar bersama, sehingga anak tidak kurang perhatian dan merasa diperhatikan oleh orang tuanya. Karena pada usia pre school tersebut sangat penting bagi anak mendapatkan perhatian dari orang tua mereka agar perkembangan psikososial tidak terganggu.

Tujuan umum dari penelitian ini adalah untuk menganalisis hubungan pola asuh orang tua dengan perkembangan psikososial anak usia prasekolah di TK PKK XI Winong Kecamatan Gempol Kabupaten Pasuruan, sedangkan tujuan khusus dari penelitian ini adalah mengidentifikasi pola asuh yang di terapkan pada orang tua anak, mengidentifikasi perkembangan psikososial anak, dan menganalisis hubungan pola asuh orang tua dengan perkembangan psikososial anak di TK PKK XI Winong Kecamatan Gempol Kabupaten Pasuruan.

\section{METODE DAN BAHAN}

Jenis penelitian yang digunakan adalah cross sectional yaitu menganalisis hubungan pola asuh orang tua dan perkembangan psikososial anak prasekolah di TK PKK XI Winong Gempola dengan cara pendekatan dan observasi atau pengumpulan data sekaligus pada suatu saat.

Populasi pada penelitian ini adalah orang tua murid di TK PKK XI Winong Gempol Kabupaten Pasuruan. Populasi pada penelitian ini berjumlah 41 (empat puluh satu) orang. Kriteria populasi pada penelian ini yaitu orang tua yang bersedia diteliti, orang tua yang anaknya bersekolah di TK, orang tua yang ke-duanya bekerja.

Sampel diambil dengan mengguanakan teknik random sampling. Pengumpulan data dengan mengguanak kuesioner. Pengambilan sampel pada penelitian ini dilakukan pada orang tua yang keduanya bekerja di TK PKK XI Winong Kecamatan Gempol Kabupaten 
Pasuruan sesuai dengan jumlah yang sudah dihitung dalam rumus besaran sampel, setelah itu lembar persetujuan menjadi responden akan diberikan kepada siswa dan akan dikumpulkan lagi ke-esokan harinya. Lalu jika sudah terkumpul orang tua yang memenuhi kriteria yang sudah ditentukan maka akan dipilih menjadi responden. Kemudian dari responden yang telah terpilih tersebutakan diberi kuesioner untuk pengumpulan data. Kuesioner yang sudah dibagi akan dikumpulkan kembali kepada peneliti jika sudah terisi semua.

\section{HASIL PENELITIAN}

\section{USIA}

Berikut ini adalah tabel distribusi berdasarkan usia di TK PKK XI Winong Kecamatan Gempol Kabupaten Pasuruan.

Tabel 1. Distribusi Berdasarkan usia di TK PKK Winong Kecamatan Gempol Kabupaten Pasuruan.

\begin{tabular}{|c|c|c|c|}
\hline No. & Usia & Frekuensi & Presentase (\%) \\
\hline 1. & 4 Tahun & 0 & 0 \\
\hline 2. & 5 Tahun & 21 & 56,8 \\
\hline 3. & 6 Tahun & 13 & 35,1 \\
\hline 4. & 7 Tahun & 3 & 8,1 \\
\hline & Total & 37 & 100 \\
\hline
\end{tabular}

Berdasarkan tabel $\quad 1$ menggambarkan bahwa sebagian besar responden berusia 5 tahun yaitu sebanyak 21 anak.

\section{JENIS KELAMIN}

Berikut ini adalah tabel distribusi subyek berdasarkan jenis kelamin di TK PKK XI Winong Kecamatan Gempol Kabupaten Pasuruan.
Tabel 2. Distribusi Subyek Berdasarkan Jenis Kelamin Di TK PKK Winong Kecamatan Gempol Kabupaten Pasuruan.

\begin{tabular}{|l|l|c|c|}
\hline No. & Jenis Kelamin & Frekuensi & $\begin{array}{c}\text { Presentase } \\
(\%)\end{array}$ \\
\hline 1. & Laki-laki & 21 & 56,8 \\
\hline 2. & Perempuan & 16 & 43,2 \\
\hline & Total & 37 & 100 \\
\hline
\end{tabular}

Berdasarkan tabel 2 responden dalam penelitian ini sebagian besar adalah laki-laki yaitu sebanyak 21 anak.

\section{POLA ASUH ORANGTUA}

Berikut ini adalah tabel hasil pengukuran pola asuh orang tua di TK PKK XI Winong Kecamatan Gempol Kabupaten Pasuruan.

Tabel 3. Hasil Pengukuran Pola Asuh Orang Tua Di TK PKK XI Winong Kecamatan Gempol Kabupaten Pasuruan.

\begin{tabular}{|c|l|c|c|}
\hline No. & Pola Asuh & Frekuensi & $\begin{array}{c}\text { Presentase } \\
(\boldsymbol{\%})\end{array}$ \\
\hline 1. & Otoriter & 7 & 18,9 \\
\hline 2. & Demokratis & 21 & 56,8 \\
\hline 3. & Permisif & 9 & 24,3 \\
\hline & Total & 37 & 100 \\
\hline
\end{tabular}

Dari tabel diatas di dapatkan bahwa orang tua yang mengguanakan pola asuh otoriter sebanyak $18,9 \%$, demokratis 56,8 $\%$, dan permisif $24,3 \%$. 
Tabel 4. Hasil Pengukuran Sesuai Indikator Pola Asuh Orang Tua Di TK PKK XI Winong Kecamatan Gempol Kabupaten Pasuruan.

\begin{tabular}{|l|c|c|c|c|c|}
\hline Indikator & $\begin{array}{c}\text { Penentuan } \\
\text { Pola Asuh }\end{array}$ & $\begin{array}{c}\text { Ganjaran } \\
\text { Peraturan } \\
\text { Atau } \\
\text { Anak } \\
\text { Pujian } \\
\text { Pada } \\
\text { Anak }\end{array}$ & $\begin{array}{c}\text { Perundingan } \\
\text { Pada Anak }\end{array}$ & $\begin{array}{c}\text { Hukuman } \\
\text { Yang } \\
\text { Diberikan } \\
\text { Pada Anak }\end{array}$ & $\begin{array}{c}\text { Keingi } \\
\text { nan } \\
\text { Anak }\end{array}$ \\
\hline Mean & 80,63 & 83,78 & 85,13 & 59,45 & 81,08 \\
\hline Median & 83,33 & 100,00 & 100,00 & 50,00 & 100,00 \\
\hline Mode & 83,33 & 100,00 & 100,00 & 50,00 & 100,00 \\
\hline Std. & 21,69 & 23,72 & 25,99 & 35,03 & 22,96 \\
Deviation & & & & & \\
\hline Minimum & 0,00 & 50,00 & 0,00 & 0,00 & 33,33 \\
\hline Maximum & 100,00 & 100,00 & 100,00 & 100,00 & 100,00 \\
\hline
\end{tabular}

Dari tabel diatas diketahui bahwa hasil pengukuran pola asuh orang tua dari 37 sampel sesui dengan indikator menunjukkan nilai rerata pada indikator penentuan peraturan pada anak : 80,63, ganjaran atau pujian pada anak : 83,78, perundingan pada anak : 85,13 , hukuman yang diberikan pada anak : 59,45, dan keinginan anak : 81,08. Untuk standard difiasi dipatkan 21,69 penentuan peraturan pada anak, 23,72 ganjaran atau pujian pada anak, 25,99 perundingan pada anak, 35,03 hukuman yang diberikan pada anak, 22,96 keinginan anak.Nilai minimum untuk indikator penentuan peraturan pada anak : 0,00, ganjaran atau pujian pada anak : 50,00, perundingan pada anak : 0,00, hukuman yang diberikan pada anak : 0,00, keinginan anak : 33,33.

Dari hasil pengukuran pola asuh didapatkan bahwa nilai signifikan untuk variable pola asuh adalah 0,00 karena $\mathrm{p}<$ 0,05 maka dapat disimpulkan bahwa data tersebut berdistribusi tidak normal. Karena hasilnya berdistribusi tidak normal maka yang sebelumnya menggunakan uji korelasi pearson diganti dengan menggunakan uji korelasi spearman rho.

\section{PERKEMBANGAN PSIKOSOSIAL}

Berikut ini adalah tabel hasil pengukuran perkembangan psikososial anak di TK PKK XI Winong Kecamatan Gempol Kabupaten Pasuruan.

Tabel 5. Hasil Pengukuran Perkembangan Psikososial Di TK PKK XI Winong Kecamatan Gempol Kabupaten Pasuruan.

\begin{tabular}{|l|l|c|c|}
\hline No. & Psikososial & Frekuensi & $\begin{array}{c}\text { Presentase } \\
(\boldsymbol{\%})\end{array}$ \\
\hline 1. & Inisiatif & 27 & 73,0 \\
\hline 2. & Guilty & 10 & 27,0 \\
\hline & Total & 37 & 100 \\
\hline
\end{tabular}

Dari tabel di dapatkan bahwa perkembangan psikososial anak di TK PKK XI Winong Gempol adalah 73,0 \% inisiatif dan $27,0 \%$ guilty.

Tabel 6. Hasil Pengukuran Sesuai Indikator Perkembangan Psikososial Anak Prasekolah di TK PKK XI Winong Kecamatan Gempol Kabupaten Pasuruan.

\begin{tabular}{|l|l|l|l|}
\hline $\begin{array}{c}\text { Indikator } \\
\text { Perkembangan } \\
\text { Psikososial }\end{array}$ & $\begin{array}{c}\text { Hubungan } \\
\text { Orang Tua } \\
\text { Dengan } \\
\text { Anak }\end{array}$ & $\begin{array}{c}\text { Hubungan } \\
\text { Dengan } \\
\text { Saudara }\end{array}$ & $\begin{array}{c}\text { Hubungan } \\
\text { Dengan } \\
\text { Sanak } \\
\text { Keluarga }\end{array}$ \\
\hline Mean & 85,40 & 61,08 & 55,67 \\
\hline Median & 80,00 & 60,00 & 60,00 \\
\hline Mode & 100,00 & 60,00 & 60,00 \\
\hline Std. Deviation & 16,76 & 18,22 & 21,67 \\
\hline Minimum & 40,00 & 20,00 & 0,00 \\
\hline Maximum & 100,00 & 100,00 & 100,00 \\
\hline
\end{tabular}

Dari tabel diatasi dapat diketahui hasil dari 37 responden menunjukkan nilai rerata dari indikator hubungan orang tua dengan anak didapatkan 85,40, hubungan dengan saudara : 61,08,dan hubungan dengan sanak keluarga : 55,67. Untuk 
standard deviation didapatkan, 16,76 hubungan orang tua dan anak, 18,22 hubungan dengan saudara, 21,67 hubungan degan sanak keluarga.Dengan nilai maksimum yang didapatkan untuk hubungan orang tua dan anak : 40,00, hubungan dengan saudara ; 20,00, hubungan dengan sanak keluarga : 0,00 dan nilai minimum hubungan dengan orang tua 100,00, hubungan dengan saudara : 100,00 dan hubungan dengan sanak keluarga : 100,00

Dari hasil pengukuran perkembangan psikososial didapatkan bahwa nilai signifikan untuk variable perkembangan psikososial adalah 0,00. Karena nila $\mathrm{p}<0,05$ pada variable perkembangan psikososial dapat disimpulkan bahwa data tersebut berdistribusi tidak normal. Karena hasilnya berdistribusi tidak normal maka yang sebelumnya menggunakan uji korelasi pearson diganti dengan menggunakan uji korelasi spearman rho.

\section{HUBUNGAN POLA ASUH ORANG} TUA DENGAN PERKEMBANGAN PSIKOSOSIAL ANAK DI TK PKK XI WINONG KECAMATAN GEMPOL KABUPATEN

\section{PASURUAN}

Berikut ini adalah grafik dari hubungan pola asuh orang tua dengan perkembangan psikososial di TK PKK XI Winong Kecamatan Gempol Kabupaten Pasuruan.

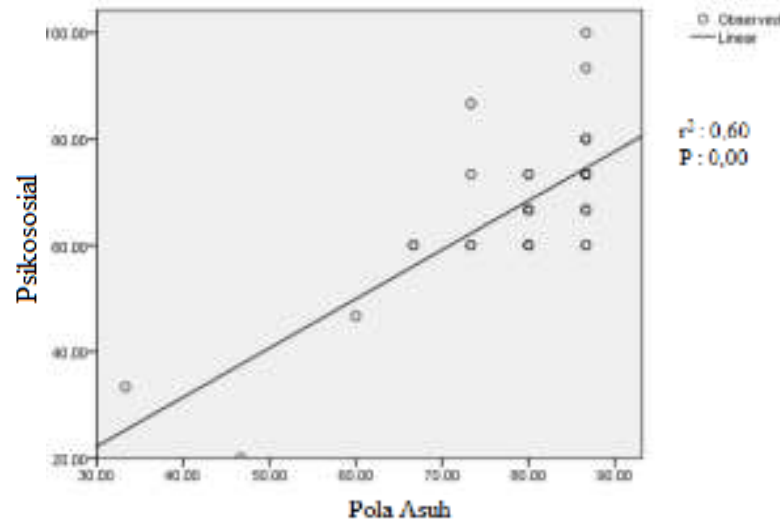

Gambar 1. Grafik Hubungan Pola Asuh Orang Tua dengan Perkembangan Psikososial di TK PKK XI Winong Kecamatan Gempol Kabupaten Pasuruan

Hubungan Pola Asuh Orang Tua dengan Perkembangan Psikososial Anak di TK PKK XI Winong Kecamatan Gempol Kabupaten Pasuruan menunjukkan nilai signicancy 0.00 yang artinya bahwa korelasi antara pola asuh dengan perkembangan psikososial anak adalah bermakna dengan nilai korelasi Spearman Rho sebesar 0,60. Karena garis linier pada gambar diatas meningkat maka dapat disimpulkan bahwa terdapat hubungan positif antara variable pola asuh dan variable perkembangan psikososial (Murray, 2004).

\section{PEMBAHASAN}

\section{Pola Asuh Orang Tua}

Dari hasil penelitian didapatkan untuk pola asuh orang tua di TK PKK XI Winong Kecamatan Gempol Kabupaten Pasuruan sebagian besar orang tua menerapkan pola asuh demokratis pada anaknya.

Menurut Khon (2006), pola asuh merupakan interaksi antara anak dengan orang tua selama mengadakan kegiatan pengasuhan. Pengasuhan ini berarti orang tua mendidik, kedewasaan sesuai dengan 
norma-norma yang ada dalam masyarakat. Menurut (Wong, 2008) pola asuh orang tua dibagi menjadi 3 yaitu pola asuh otoriter merupakan pola asuh dimana orang tua akan membuat berbagai aturan yang harus dipatuhi oleh anaknya, tanpa mau mengetahui perasaan anak, demokratis adalah pola asuh orang tua pada anak yang member kebebasan pada anak untuk berkreasi dan bereksplorasi berbagai hal sesuai dengna kemampuan anak dengan sensor batas dan pengawasan yang baik dari orang tua dan permisif adalah pola asuh dimana orang tua jarang atau tidak pernah mengontrol perbuatan anaknya.

Dari pernyataan tersebut sebagian besar orang tua yang menerapkan pola pengasuhan bersifat demokratis, dimana pola asuh demokratis merupakan pola pengasuhan tidak membatasi keinginan dan tindakan yang dilakukan oleh anaknya selama anak tersebut tidak menyalahi norma-norma yang berlaku. Dan dari setiap indikator dalam pola asuh rerata yang terbanyak adalah perundingan pada anak. Dimana perundingan pada anak sangat mempengaruhi, karena dengan cara berunding maka orang tua akan tau dan mengerti apa yang diinginkan anaknya dan dapat memikirkan apakah keinginan tersebut baik untuk anaknya.

\section{Perkembangan Psikososial Anak Prasekolah}

Hasil penelitian menunjukkan bahwa perkembangan psikosososial anak di TK PKK XI Winong Kecamatan Gempol adalah inisiatif.

Tinjauan Erickson dalam Muscari (2005) masalah psikososial, mengatakan krisis yang dihadapi anak pada usia antara 3 dan 6 tahun disebut "inisiatif versus rasa bersalah". Dimana orang terdekat anak usia prasekolah adalah keluarga, anak normal telah menguasai perasaan otonomi, anak mengembangkan perasaan bersalah ketika orang tua membuat anak merasa bahwa imajinasi dan aktivitasnya tidak dapat diterima.

Perkembangan inisiatif anak akan muncul jika anak dapat mengembangkan imajinasi dan aktivitasnya tanpa ada penolakan dan pengekangan dari orang tua. Dan nilai rerata yang terbanyak yang didapatkan dari indikator perkembangan psikososial adalah hubungan orang tua dengan anak. Dimana hubungan orang tua dengan anaknya sangat penting karena semakin erat dan semakin terbuka orang tua kepada anaknya maka anakpun juga dapat secara bebas mengungkapkan apa yang diinginkannya dan orang tua juga dapat memilah, apakah keinginan anak tersebut menyalahi norma atau tidak.

\section{Hubungan Pola Asuh Orang Tua dengan Perkembangan Psikososial}

Dari hasil uji spearman menunjukkan bahwa variable pola asuh orang tua dan variable perkembangan psikososial menunjukkan adanya hubungan dengan kekuatan sedang, dengan garis linier pada gambar yang menujuk keatasa yang menunjukkan bahwa ada hubungan positif.

Menurut Marini (2005) Keluarga merupakan tempat pendidikan pertama bagi anak-anak. Orang tua memiliki peran sebagai pendidik, pembimbing dan pelindung bagi anak-anaknya sehingga mereka dapat tumbuh dan berkembang sesuai dengan kepribadiannya. Pola asuh orang tua yang baik dapat mempengaruhi perkembangan psikososial anaknya, hal tersebut didukung oleh teori Baumrind (2006) dimana orang tua dengan pola asuh otoriter menetapkan kendali dan tuntutan 
yang tinggi pada anak Sedangkan pada pola asuh demokratis, orang tua menerapkan sikap demokratis, kasih sayang, adanya tuntutan serta mengendalikan anak.

Perilaku orang tua yang menggunakan pola asuh demokratis bilamana orang tua tidak membatasi aktivitas anak selama aktivitas tersebut tidak menyalahi norma yang ada, sehingga dari sikap itulah akan memicu munculnya rasa inisiatif anak dengan sendirinya. Karena semakin orang tua membebaskan anak untuk mengungkapkan apa yang diinginkannya, orang tua akan tahu keinginan anak yang sebenarnya dan orang tua juga dapat memilah apakah keinginannya tersebut baik dan tidak menyalahi aturan yang ada.

\section{SIMPULAN}

1. Pola asuh yang diterapkan oleh orang tua di TK PKK XI Winong Kecamatan Gempol Kabupaten Pasuruan kebanyakan adalah pola asuh permissive.

2. Perkembangan psikososial anak di TK PKK XI Winong Kecamatan Gempol Kabupaten Pasuruan adalah inisiatif.

3. Ada hubungan antara pola asuh orang tua dengan perkembangan psikososial anak di TK PKK XI Winong Kecamatan Gempol Kabupaten Pasuruan.

\section{SARAN}

Saran dalam penelitian ini adalah setiap orangtua hendaknya memperhatikan pola asuh yang digunakan sehingga perkembangan psikososial anaknya.

\section{DAFTAR PUSTAKA}

1. Asrori. Mohammad. 2007. Psikologi Pembelajaran. Bandung : CV. Wacana Prima
2. Bahri, S. 2004. Pola Komunikasi Orang Tua \& Anak Dalam Keluarga. Jakarta : Rineka Cipta

3. Bastable. Susan B. 2002. Perawat Sebagai Pendidik. EGC : Jakarta

4. Devi \& Yanti. 2005. Hubungan kekerasan pada anak terhadap gangguan perilaku.

5. Donna L.Wong. 2008. Buku Ajar Keperawatan Pediatrik Wong. edisi 6. Jakarta : EGC

6. Desmita. 2007. Psikologi Perkembangan. Bandung : PT Remaja Rusdakarya

7. Depdikbud. 1988. Kamus Besar Bahasa Indonesia. Jakarta : Balai Pustaka

8. Drs.H. Ahmad Abu. 2009. Psikologi Sosial Edisi Refisi. Jakarta : PT Rineka Cipta

9. Dariyo A. 2007. Psikologi Perkembangan Anak Tiga Tahun Pertama. Bandung :PT Refika Aditama

10. Hidayat D.R. 2009. Pengantar Psikologi untuk Tenaga Kesehatan. Ilmu Perilaku Manusia, Jakarta : CV Trans Info Media

11. Hurlock, Elizabeth B. 2002. Psikologi Perkembangan Edisi Kelima. Jakarta: Erlangga

12. Hockenberry, M.J., \& Wilson, D. 2007. Nursing care of infants and children.

13. Keliat B. 2008. Perawatan Kesehatan Jiwa. Jakarta : Erlangga

14. Mary E, Muscari. 2005. Keperawatan Pediatrik. edisi 3. cetakan 1. EGC : Jakarta

15. Nursalam. dkk. 2005. Asuhan Keperawatan Bayi Dan Anak (Untuk Perawat Dan Bidan). Jakarta : Salemba Medika 
16. Potter, P.A \& Perry, A.G. 2005. Fundamental of nursing: concepts, process, and practice. Edisi 4. Cetakan Kesatu. Jakarta: EGC.

17. Papalia, D. E., \& Feldman, R. D. 1998. Human development (12th Ed.). NY: McGraw-Hill. King, L. (2008)

18. Petranto, Ira. 2006. Rasa Percaya Diri Adalah Pantulan Pola Asuh Orang Tuanya

19. Rina M. Taufik. 2007. Pola Asuh Orang Tua. http://www.tabloid_nakita.com. (Asscesed, 8th April, 12.15 pm)

20. Rudolph M. Abraham dkk. 2006. Buku Ajar Pediatri Rudolph, vol.1 ,ed.20. Jakarta : EGC

21. Riyadi, Sujono \& Sukarmin. 2009. Asuhan Keperawatan Pada Anak. Yogyakarta : Graha Ilmu

22. Santrock, JW. 2011. Masa Perkembangan Anak. Jakarta : Salemba Humanika

23. Shochib. M. 2001. Pengantar Psikologi Perkembangan Anak dan Remaja. Jakarta : PT. BPK, Gunung Mulia

24. Syamsu Yusuf, L.N. 2004. Psikologi Perkembangan Anak dan Remaja. Bandung : Remaja Rosdakarya

25. Soetjiningsih. 2004. Tumbuh Kembang Anak, Jakarta : EGC

26. Susanto. Ahmad. 2011. Perkembangan Anak Usia Dini. Jakarta : Kencana

27. Suparyanto. 2009. Pola Asuh. http://uidb4.wikispaces.com Tanggal 11 September 2010. Jam 11.17 WIB

28. TIM Penyusun Kamus Pusat Pembinaan dan Pengembangan Bahasa. 1988. Kamus Besar Bahasa Indonesia. Jakarta : Balai Pustaka.

29. Theresia S. Indira. 2008. Pola Asuh Penuh Cinta. http://www.polaasuh penuhcinta.com. (Asscesed, 8th April, $12.15 \mathrm{pm}$ ) 